\title{
Facebook and Education: Students' Privacy Concerns
}

\author{
Yahya Mohammed Al-Dheleai ${ }^{1} \&$ Zaidatun Tasir ${ }^{1}$ \\ ${ }^{1}$ Department of Educational Science, Mathematics and Creative Multimedia, Faculty of Education, Universiti \\ Teknologi Malaysia, Johor Bahru, Malaysia \\ Correspondence: Zaidatun Tasir, Department of Educational Science, Mathematics and Creative Multimedia, \\ Faculty of Education, Universiti Teknologi Malaysia, Johor Bahru, Malaysia. E-mail: p-zaida@utm.my
}

\author{
Received: November 2, 2014 Accepted: March 12, 2015 Online Published: June 25, 2015 \\ doi:10.5539/ies.v8n13p22 URL: http://dx.doi.org/10.5539/ies.v8n13p22
}

\begin{abstract}
In this article, the focus is on students' privacy concern towards the use of Facebook for educational purpose. The authors of this article discussed the issue based on the findings of the previous studies. The review of the literature showed that students are more concerned about invading their privacy when interacting with their professors via Facebook. Authors of this article provided recommendations that can help faculty to tackle students concerns about their privacy. Additionally, provided recommendations may facilitate educational use of Facebook in higher education.
\end{abstract}

Keywords: social network, Facebook, privacy, educational use

\section{Introduction}

Through social networking tools, users can share personal information in online-based network. Websites, such as MySpace, Facebook, LinkedIn, and Twitter, made it easy for users to create profiles that include biographical information and pictures. Users may reveal their interests, contact information, photos, daily activities, associations and interactions with other users and groups (Strater \& Lipford, 2008).

Social networking tool such as Facebook was created in 2004 in Harvard University (USA). The mean purpose of Facebook was to facilitate college student communication in Harvard University. Throughout time, Facebook has been expanded to be used by other educational institutions including higher education and high schools. Later Facebook was opened to public in all countries.

Facebook users are required to provide some personal information when they create their profiles. Some users go beyond that and reveal more information. Facebook users reveal their name, address, phone number, hobbies, interest, religious and political views, daily events and even relationship status. Also Facebook users can send friend request to other Facebook users and join different groups. In Facebook, activities such as posting, commenting and like other users posts and pictures, posts thought, tag and share pictures are provided. Therefore, the number and depth of personal information disclosed through online have raised concerns regarding the online privacy.

In this article, the focus is on the issue of privacy concern regarding the use of social networking tool (Facebook) for education. The closer look to the previous studies that had discussed the issue can provide useful information to be considered while adapting such tool for educational purpose.

\section{Facebook Use among University Students}

Social networking tool (Facebook) has become an integral part of university students' daily life. Currently, Facebook use is one of the daily routine of university students around the globe. A great deal of time is spent on Facebook on students' everyday life. EDUCAUSE Center for Applied Research (ECAR) conducted a study that targeted 36,950 students from 126 US universities and one Canadian university. ECAR study found that $90 \%$ of those students are using social networking tools. $97 \%$ from social networking users were using Facebook and reported daily activity on this site (Smith, 2010). Junco (2012) found that students spend a great deal of their time on Facebook, some of them spend 100 minutes every day on the site. There are different purposes for students' use of Facebook and these usages differ from student to another. According to Wesseling (2012) four major Facebook activities were identified by previous studies. Those major activities are as the following:

1) Sharing information (receiving/providing information and generating ideas). 
2) Information sharing for educational purposes (for learning, problem solving and sharing work).

3) Social purposes (retrieving personal information about others or themselves, chatting, making appointments and generally keeping in touch).

4) Leisure time activities (gaming and relaxing).

Wesseling (2012) study revealed that students use the social networking site (Facebook) for multipurpose and in different percentage; as illustrated in table 1, the percentage of students who use the site for social purposes is $70.1 \%$ and for information exchange $70.2 \%$. The study also showed that $49.7 \%$ of students use Facebook for educational purposes. A study conducted by Hamat, Embi, and Hassan (2012) in Malaysian context found that $84 \%$ of Malaysian students use social networking sites to interact and communicate with their peers for informal learning purpose. In the other side, only 49.7 of students communicate with their lecturers for academic matters. According to Grosseck, Bran and Tiru (2011) 26.7\% of the students perceive the use of Facebook educational groups in particular, as important tool that can change the way of online learning in higher education.

Table 1. Students purposes of Facebook use

\begin{tabular}{lll}
\cline { 2 - 3 } & Purpose of use & Percentage \\
\cline { 2 - 3 } & Social purpose & $70.1 \%$ \\
& Information exchange & $70.2 \%$ \\
& Educational purpose & $49.7 \%$ \\
\hline
\end{tabular}

Sourse: Wesseling (2012).

Therefore, Muñoz and Towner (2012) confirmed that social network sites may have place in classroom as previous communication technologies have been integrated into the way faculty teach and administer courses such as Email, chat rooms, bulletin boards, etc. Several aspects made Facebook an effective educational platform. It has the features to facilitate active learning (as Facebook users engage with each other to participate in discussions or share and view posts), easy posting and sharing of current events. Facebook could also serve as an accessible, real-time, dynamic platform to allow course- related discussion (Divall \& Kirwin, 2012). Therefore, how much personal information provided by users in the Facebook should be concerned nowadays.

\section{Personal Information Disclosure on Facebook}

Facebook users readily disclose a noticeable amount of their personal information on their profiles. Strater and Lipford (2008) reported that the undergraduate students who participated in their study disclosed a large amount of personal information, such as their birthday, hometown, friends, photos, and email. Some of the participants also shared their personal information such as addresses, course schedules, and phone numbers (Strater \& Lipford, 2008). People also tend to disclose their names and birthday to the entire network but they are less willing to disclose their contact information (physical address and phone number)(Gross, Acquisti \& Iii, 2005).

In a study conducted by Dwyer and Hiltz and compared between Facebook and MySpace revealed that, Facebook members expressed significantly greater trust in both Facebook and its members, and were more willing to share identifying information that those with MySpace users (Dwyer \& Hiltz, n.d.). Similarly, Fogel and Nehmad (2009) found that Facebook has greater trust ratings than MySpace among undergraduate students. For example Dwyer and Hiltz (n.d.) reported that only 66.7\% of MySpace users who reveal their real name, while $100 \%$ of the Facebook members reveal their real name in their profile, and $94 \%$ of Facebook members include their email address, compared to only $40 \%$ of MySpace members.

Extensive privacy policy is provided by Facebook for its users. Facebook enable users to control and choose what information to reveal and to whom they disclose their personal information (Acquisti \& Gross, 2006). It is clear that Facebook has more extensive privacy settings than similar sites (Lipford, Besmer, Watson, \& Carolina, n.d.). Therefore, Facebook user has the responsibility for deciding what type of information to disclose and what level of privacy setting to use for protecting his/her personal information (Strater \& Lipford, 2008). Unfortunately, only 1.2 percent of users change the default privacy settings (Gross, Acquisti, \& Iii, 2005).

\section{Students' Privacy Concern}

Privacy in this study is the personal information that revealed publicly online by Facebook member and can be seen by other Facebook members. Facebook users disclose information such as name, gender, age relationship 
status, work place, phone number, and even home address. Also Facebook users share their social activities photos and events, express their feeling and thoughts on Facebook wall. Additionally, privacy control is the features that enable users to control who can access to his/her personal information.

In regards to students' privacy, Strater and Lipford (2008) study revealed that undergraduate student were aware of privacy concerns involved in online networking and they attempt to protect themselves. While undergraduate students expressed high concern about the privacy issue in Facebook, but vast majority (89.74\%) of them still joining Facebook (Acquisti \& Gross, 2006). The study also found that majority of the respondents who are Facebook members claim to know how to control visibility and search ability of their profiles (Acquisti \& Gross, 2006) but only 1.2 percent of users changed the default privacy settings (Gross, Acquisti, \& Iii, 2005).

Strater and Lipford (2008) reported that most of their study participants revealed that they stalked or physically located by strangers while four participants reported that unknown people contacted them outside of Facebook due to the information they had revealed on their profiles. Four reasons behind university students' private information disclosure on Facebook as mentioned by Waters and Ackerman (2011):

1) For fun and enjoyable activity;

2) It is seen "as a way to store information that is meaningful to them";

3) Private information might also help to keep up with trends; and

4) Showing off their popularity

\section{Faculty Presence on Facebook and Students' Privacy Concern}

In regards to faculty presence on Facebook, students did not expect of being friends with faculty on Facebook (Bruneel, de Wit, Verhoeven, \& Elen, 2013). Students perceived that there are a strong distinction between school and leisure time, strong awareness of the consequences of too much self-disclosure; and as students consider that faculty members are not part of students' private lives; As a result, students believe that faculty are not allowed to be friends with students (Bruneel, de Wit, Verhoeven, \& Elen, 2013). Roblyer, McDaniel, Webb, Herman, and Witty (2010) study found that $53.3 \%$ of students believe that the use of Facebook in education is inconvenient. Their findings also showed that $22.5 \%$ of students believe that Facebook is personal/social and has no relevance to education and $15 \%$ of the participant expressed that their privacy would be invaded when Facebook used for educational purpose (Roblyer, McDaniel, Webb, Herman, \& Witty, 2010). Contrary, Choi (2012) found that only $6 \%$ students were concerned or very concerned about privacy when faculty be on Facebook while $92 \%$ had no or little concern about that. This can be attributed to that in Choi's (2013) study incorporating Facebook was limited to joining group for academic purpose and faculty didn't need to friend students on Facebook group. Hewitt and Forte (2006) stated that some students conveyed a sense of anxiety about interacting with faculty. Many students indicated that the student/faculty relationship should remain professional and should not be familiar or sociable.

\section{Recommendations for Acceptable Educational Use of Facebook}

Although previous research findings revealed that students perceive the use of Facebook in education as inconvenient, however the advantages of Facebook as a medium of communication nowadays are undeniable. Therefore, few recommendations on how to use Facebook for educational purposes are as followings:

\subsection{Teacher Should Distinguish between Professional and Personal Relationship When They Use Facebook}

In this regards teacher should not friend his/her students on Facebook. Teacher can create Facebook group or separate page to be able to communicate students without adding students as friends on personal page. Furthermore, understanding the language used by students and sensitivity towards students' posts should be considered by teachers. They have to accept students as friends and at a same time gain respect from students when using Facebook in teaching and learning.

\subsection{Teacher Should Use a Separate Professional Facebook Page from Personal Page to Avoid Sensitive Personal Information Disclosure to His Students}

By creating professional page, teacher can keep professional boundaries with students. In professional Facebook page teacher do not need to share personal and private information and keep his/her personal and social contacts away from students, and keep contact with students in line with professional purpose only. Faculty also can ask students to create separate Facebook account for their learning purpose. In learning page, students can contact their teachers and classmate without worry about personal and social stuff and privacy invasion by teacher and other classmate. 


\subsection{Professors Can Use Facebook Group Feature to Be Used for Educational Purpose}

Facebook provide a group feature that allow Facebook member to create a group and allow the user to add or invite other users to join the group. One of the advantages for Facebook group is that teacher does not need to friend students when they join his/her Facebook group. Therefore, students do not have to worry much about their privacy while the teacher is not friend with them in their personal page.

5.4 Universities Should Conduct Training Programs and Campaign that Can Raise the Awareness of the Issue of Privacy and Security on Social Networking Tools

To protect students' privacy, University needs to increase students' awareness about the importance of protecting their own privacy on Facebook and other tools and the negative consequences of revealing their personal and sensitive information publicly on those tools. Awareness programs should also target faculty on how to use Facebook for educational purpose and how they deal with their own and their students' privacy matters. Additionally, conducting workshops and training programs is important to help faculty and students to deal with privacy settings on Facebook and master profile management.

\section{Conclusion}

Among social networking tool, Facebook considered as the most used by university student. Some of students believe that Facebook is a social tool and should not be used as a communication tool between faculty and students. University students are ready to interact with peers more than contacting their professors via Facebook. Both faculty and students can benefit from the power of Facebook for their educational interaction. Many ways can reduce Students concern about their privacy when contacting their teachers. Teachers may setup a separated professional page on Facebook. Facebook group and Facebook page can be another solution for teacher to interact with students without being their friend or seeing their profile. Increasing the awareness about the privacy setting that provided by Facebook and the way to use it can also overcome concern about privacy among student and faculty members.

\section{Acknowledgements}

The authors would like to thank the Universiti Teknologi Malaysia (UTM) and Ministry of Education (MOE) Malaysia for their support in making this project possible. This work was supported by the Research University Grant [R.J130000.7831.4F116] initiated by MOE.

\section{References}

Acquisti, A., \& Gross, R. (2006). Imagined Communities: Awareness, Information Sharing, and Privacy on the Facebook (pp. 1-16). http://dx.doi.org/10.1007/11957454_3

Bruneel, S., de Wit, K., Verhoeven, J. C., \& Elen, J. (2013). Facebook: When Education Meets Privacy (p. 9).

Choi, A. (2013). Use of Facebook group feature to promote student collaboration. In 2013 ASEE Southeast Section Conference Proceedings. Retrieved from http://se.asee.org/proceedings/ASEE2013/Papers2013/112. PDF

Divall, M. V., \& Kirwin, J. L. (2012). Using Facebook to Facilitate Course-Related Discussion Between Students and Faculty Members, 76(2), 1-5.

Dwyer, C., \& Hiltz, S. R. (n.d.). Trust and privacy concern within social networking sites: A comparison of Facebook and MySpace.

Fogel, J., \& Nehmad, E. (2009). Internet social network communities: Risk taking, trust, and privacy concerns. Computers in Human Behavior, 25(1), 153-160. http://dx.doi.org/10.1016/j.chb.2008.08.006

Gross, R., Acquisti, A., \& Iii, H. J. H. (2005). Information Revelation and Privacy in Online Social Networks (pp. 71-80).

Grosseck, G., Bran, R., \& Tiru, L. (2011). Dear teacher, what should I write on my wall? A case study on academic uses of Facebook. Procedia-Social and Behavioral Sciences, 15, 1425-1430. http://dx.doi.org/10.1016/j.sbspro.2011.03.306

Hamat, A., Embi, M. A., \& Hassan, H. A. (2012). The Use of Social Networking Sites among Malaysian University Students. International Education Studies, 5(3), 56. http://dx.doi.org/10.5539/ies.v5n3p56

Hewitt, A., \& Forte, A. (2006). Crossing Boundaries: Identity Management and Student/Faculty Relationships on the Facebook (p. 38).

Junco, R. (2012). Too much face and not enough books: The relationship between multiple indices of Facebook 
use and academic performance. Computers in Human Behavior, 28(1), 187-198. http://dx.doi.org/10.1016/j.chb.2011.08.026

Lipford, H. R., Besmer, A., Watson, J., \& Carolina, N. (n.d.). Understanding Privacy Settings in Facebook with an Audience View.

Muñoz, C. L., \& Towner, T. L. (2009). Opening Facebook: How to Use Facebook in the College Classroom (pp. $1-13)$.

Roblyer, M. D., McDaniel, M., Webb, M., Herman, J., \& Witty, J. V. (2010). Findings on Facebook in higher education: A comparison of college faculty and student uses and perceptions of social networking sites. The Internet and Higher Education, 13(3), 134-140. http://dx.doi.org/10.1016/j.iheduc.2010.03.002

Smith, S. D. (2010). 2010 The ECAR Study of Undergraduate Students.

Strater, K., \& Lipford, H. R. (2008). Strategies and Struggles with Privacy in an Online Social Networking Community.

Waters, S., \& Ackerman, J. (2011). Exploring Privacy Management on Facebook: Motivations and Perceived Consequences of Voluntary Disclosure. Journal of Computer-Mediated Communication, 17(1), 101-115. http://dx.doi.org/10.1111/j.1083-6101.2011.01559.x

Wesseling, N. (2012). How students use Facebook (pp. 20-25).

\section{Copyrights}

Copyright for this article is retained by the author(s), with first publication rights granted to the journal.

This is an open-access article distributed under the terms and conditions of the Creative Commons Attribution license (http://creativecommons.org/licenses/by/3.0/). 